\title{
EVALUASI PROSES PENGANGGARAN DANA BANTUAN OPERASIONAL SEKOLAH (BOS) DI KABUPATEN PURWOREJO
}

\author{
EVALUATION OF THE BUDGETING PROCESS DANA BANTUAN \\ OPERASIONAL SEKOLAH (BOS) IN KABUPATEN PURWOREJO
}

\author{
Rusmiyatun ${ }^{1)}$ \\ ${ }^{1)}$ STIE Rajawali Purworejo \\ Jl. Gajah Mada No.KM. 7, Dukuh, Dukuhrejo, Kec. Bayan, Kabupaten Purworejo, Jawa \\ Tengah 54224 \\ rose.mia2691@gmail.com
}

\begin{abstract}
ABSTRAK
Penelitian ini bertujuan untuk mengevaluasi proses penganggaran Dana Bantuan Operasional Sekolah di Kabupaten Purworejo. Pengukuran Evaluasi menggunakan Indikator yang dikeluarkan oleh United Nations Development Programme (UNDP) tentang Good Governance dengan variabel Transparansi dan Akuntabilitas dalam proses penganggaran di Kabupaten Purworejo. Sample dari Penelitian ini adalah 477 Sekolah di Kabupaten Purworejo dan Tim Manajemen BOS Kabupaten Purworejo di Dinas Pendidikan, Kepemudaan dan Olahraga Kabupaten Purworejo. Hasil penelitian menunjukkan secara umum pelaksanaan Prinsip Good governance untuk akuntabilitas telah terlaksana dengan baik dan memenuhi prinsip prinsip akuntabilitas. Bahkan Nilai Akuntabilitas Kinerja keseluruhan Kabupaten Purworejo memperoleh nilai kinerja AA ( Sangat memuaskan ). Sedangkan untuk Prinsip Transparansi yang diukur dengan kerangka kerja hukum, ketersediaan informasi publik, keterbukaan rencana, pelaksanaan dan pelaporan telah terlaksana cukup baik namun beberapa sekolah masih belum menaati adanya transparansi keterbukaan untuk bidang pelaporan . masih ada 26,7 \% sekolah yang belum melaporkan online di website kemdikbud.
\end{abstract}

Kata Kunci: Good Governance, Akuntabilitas,Transparansi, Kabupaten Purworejo, Anggaran, Dana BOS.

\begin{abstract}
This study aims to evaluate the budgeting process for School Operational Assistance Funds in Purworejo Regency. Evaluation measurement uses indicators issued by the United Nations Development Program (UNDP) on Good Governance with Transparency and Accountability variables in the Budgeting Process in Purworejo Regency. The samples of this study were 477 schools in Purworejo Regency and the BOS Management Team in Purworejo Regency in the Education, Youth and Sports Office of Purworejo Regency. The results showed that in general the implementation of the principles of good governance for accountability had been carried out well and met the principles of accountability. Even the overall Performance Accountability Score of Purworejo Regency gets a performance score of AA (Very satisfying). Meanwhile, for the Transparency Principle as measured by the legal framework, the availability of public information, open plan planning, implementation and reporting have been carried out quite well, but several schools still do not comply with the transparency of openness in the reporting sector. there are still 26,7\% of schools that have not reported online on the Ministry of Education and Culture's website.
\end{abstract}

Keywords: Good Governance, Accountability, Transparency, Purworejo Regency, Budget, BOS Funds. 


\section{SEGMEN Jurnal Manajemen dan Bisnis \\ Volume 17 No 2 Juli 2021 \\ p-ISSN: 0216-938X e-ISSN: 2684-8414}

\section{PENDAHULUAN}

Penerapan tata kelola yang baik atau lebih dikenal dengan Good Corporate Governance (GCG) perlu diimplementasikan dalam semua sektor. Salah satu rekomendasi yang disampaikan International Monetary Fund (IMF) untuk Indonesia mulai mengimplementasikan prinsip tata kelola yang baik atau lebih dikenal dengan Good Corporate Governance (GCG). Prinsip ini pada awalnya diterapkan pada sektor korporasi yang pelaksanaannya dikawal oleh Komite Nasional mengenai Kebijakan Corporate Governance (KNKCG) yang dibentuk melalui Keputusan Menteri Koordinator Bidang Ekonomi, Keuangan dan Industri (Ekuin) Nomor KEP31/M.EKUIN/06/2000. Selanjutnya, prinsip inidikembangkan untuk diterapkan juga pada sektor publik dalam rangka peningkatan pelayanan pada masyarakat.

Karena hal itu pemerintah menerbitkan Pemerintah juga menerbitkan Peraturan Presiden Nomor 81 Tahun 2010 tentang Grand Design Reformasi Birokrasi 2010-2025 yang dibuat dalam rangka mempercepat tercapainya tata kelola pemerintahan yang baik di seluruh kementerian/lembaga dan pemerintah daerah .

Bantuan Operasional Sekolah (BOS) merupakan program pemerintah yang berasal dari dana subsidi BBM yang bertujuan untuk meringankan beban biaya pendidikan yang dibayar oleh masyarakat dengan tetap mempertahankan mutu pendidikan (Wardani, dkk 2010). Sesuai dengan Peraturan Menteri Pendidikan dan Kebudayaan Republik Indonesia Nomor 6 Tahun 2021 tentang Petunjuk Teknis Penggunaan Dana BOS Reguler mendefinisikan bahwa "BOS adalah Dana yang digunakan terutama untuk mendanai belanja non personalia bagi satuan pendidikan dasar dan menengah sebagai pelaksana program wajib belajar dan dapat dimungkinkan untuk mendanai beberapa kegiatan lain sesuai dengan ketentuan peraturan perundang-undangan satuan pendidikan. Dana BOS terdiri dari 3 macam yaitu BOS reguler, BOS Afirmasi dan BOS Kinerja.

Dana BOS Reguler diberikan untuk kegiatan operasional seluruh sekolah negeri dan swasta dengan kriteria yang masuk sesuai peunjuk teknis. BOS Afirmasi adalah program pemerintah pusat yang dialokasi bagi satu pendidikan dasar dan menengah yang ada di daerah khusus. BOS Kinerja merupakan dana yang dialokasi bagi sekolah yang memiliki kinerja baik dalam menyelenggarakan layanan pendidikan di daerah khusus yang ditetapkan oleh kementerian.

Biaya BOS yang diterima oleh SD/SDLB dihitung berdasarkan jumlah peserta didik pada sekolah yang bersangkutan, mulai pada tahun 2019 besaran dana untuk penerima BOS meningkat $2,4 \%$ dari tahun sebelumnya dengan rincian satuan biaya SD/SDLB sebesar Rp.900.000/peserta didik/tahun dan disalurkan dalam 1 tahun sebanyak 3 tahap. Tahap 1 sebesar $30 \%$ untuk Januari - April, Tahap 2 sebesar $40 \%$ untuk Mei - Agustus, Tahap 3 sebesar $30 \%$ untuk bulan September - Desember. Alokasi Tahap 2 dianggarkan lebih besar untuk penganggaran pembelanjaan pembelian buku di tahap kedua.

Tim yang terlibat di dalam pengelolaan BOS adalah Tim Manajemen BOS Pusat, Tim Manajemen BOS Provinsi,

Rusmiyatun: Evaluasi Proses Penganggaran Dana Bantuan Operasional Sekolah (BOS) di Kabupaten Purworejo 


\section{SEGMEN Jurnal Manajemen dan Bisnis \\ Volume 17 No 2 Juli 2021 \\ p-ISSN: 0216-938X e-ISSN: 2684-8414}

Tim Manajemen BOS Kabupaten/Kota, dan sekolah. Dana BOS diterima oleh sekolah secara utuh langsung masuk ke rekening dan dikelola secara mandiri oleh sekolah dengan melibatkan kepala sekolah sebagai penanggungjawab, bendahara BOS, dewan guru, komite sekolah dan orangtua diluar komite sekolah . Dalam pengelolaan BOS terlebih dahulu melakukan rapat komite diawal

tahun untuk menyusun Rencana Kegiatan dan Anggaran Sekolah (RKAS). RKAS merupakan susunan program kerja disertai rincian rencana pembiayaannya dalam satu tahun anggaran. Penggunaan dana BOS harus didasarkan pada kesepakatan dan keputusan bersama. Sesuai dalam buku petunjuk teknis penggunaan dana BOS hanya membiayai komponenkomponen kegiatan tertentu, seperti pembelian/pengadaan buku pelajaran, kegiatan pembelajaran dan ekstra kurikuler siswa, perawatan sekolah, pembayaran honorarium bulanan guru honorer dan lain sebagainya.

Setelah menggunakan dana BOS langkah selanjutnya yaitu pertanggungjawaban. Dalam salah satu bentuk pertanggungjawaban pelaksanaan program BOS masing-masing pengelola diwajibkan untuk melaporkan hasil kegiatannya kepada pihak terkait. Secara umum laporan pertanggungjawaban terdiri dari kelengkapan pembukuan seperti buku kas umum, buku pembantu kas, buku pembantu bank, buku pembantu pajak, realisasi penggunaan dana, rekapitulasi dana per triwulan dan per satu tahun dan berita acara. Berdasarkan prosedur yang ada, dana BOS dikelola secara relevan dan efektif yaitu tujuan yang direncanakan semula benar-benar tercapai.
Sebelum penggunaan Dana BOS Sekolah harus melakukan proses penganggaran terlebih dahulu. Masih Banyaknya sekolah yang tidak tertib melakukan penganggaran menyebabkan adanya masalah apabila sekolah dikunjungi BPK untuk audit. Karena tim Badan Pemeriksa Keuangan (BPK) menyamakan jumlah anggaran dan realisasi yang dilakukan oleh satuan pendidikan. Karena itu perlu dilakukan kajian evaluasi untuk sektor penganggaran Dana Bantuan Operasional Sekolah di Kabupaten Purworejo. Penelitian ini juga bermanfaat untuk Dinas Pendidikan, Kepemudaan dan Olahraga Kabupaten Purworejo sebagai supervisor sekolah untuk bisa melakukan Monitoring dan evaluasi yang lebih baik.

Penelitian terkait penganggaran Dana BOS telah banyak dilakukan oleh peneliti terdahulu, Nurul (2015) Skala prioritas dan tingkat Kepentingan akuntabilitas antara Bendahara dan Kepala Sekolah dalam pengelolaan Dana BOS seringkali berbeda sehingga terjadi konflik kepentingan. Alokasi penggunaan dana bantuan juga belum ada pagu baku dalam hal pengeluarannya.

Penelitian tentang efektivitas dan efisiensi pengelolaan dana BOS pernah dilakukan oleh Gede Andreyan (2014) dalam penelitian yang dilakukan terdapat tiga indikator yang digunakan dalam menentukan efektivitas pengelolaan dana BOS yaitu perencanaan, pelaksanaan dan pertanggungjawaban dengan persentase $87 \%$ yang artinya sekolah mampu melakukan sesuatu sesuai peraturan. Yuni (2019) juga mengungkapkan rawannya penyelewengan Dana BOS meningkat karena adanya temuan KPK dan BPK dalam audit yang dilaksanakan di lapangan. 


\section{SEGMEN Jurnal Manajemen dan Bisnis \\ Volume 17 No 2 Juli 2021 \\ p-ISSN: 0216-938X e-ISSN: 2684-8414}

Pada penelitian Dedy (2018) menyatakan bahwa tingkat efektivitas dan efisiensi pengelolaan dana BOS menekankan pada pelaksanaan pembiayaan, proses pengelolaan pembiayaan pendidikan dikatakan sangat efektif dilihat dari hasil hubungan biaya dan manfaat. Hasil kajian KPK mendapati bahwa kerugian negara akan terjadi manakala dana bantuan operasionalsekolah tidak dikelola secara baik berdasarkan kriteria penilaian: tidak transparan, dan tidak akuntabel. Aspek transparansi dan akuntabilitas merupakan salah satu pilar kunci good governance. Dilandasi kedua hal tersebut, maka kajian ini dibuat dengan tujuan untuk mengevaluasi sejauh mana penerapan good governance dalam proses penganggaran di Kabupaten Purworejo.

\section{EVALUASI KEBIJAKAN}

Menurut Dunn (2003), secara umum evaluasi dapat disamakan dengan penaksiran (appraisal), pemberian angka (rating), dan penilaian (assessment), sebagai usaha untuk menganalisis hasil kebijakan. Viviane dan Lansheere dalam Wrihatnolo (2011) menjelaskan bahwa hasil penilaian dapat berupa nilai kualitatif (pernyataan naratif dalam kata-kata) dan nilai kuantitatif (berupa angka). Bingham dan Felbinger dalam Lester dan Stewart Jr. (2000) mengategorikan evaluasi menjadi 4 (empat) jenis yaitu:

1. Evaluasi proses (process evaluation), yang fokus pada bagaimana proses implementasi suatu kebijakan.

2. Evaluasi dampak (impact evaluation), yang fokus pada hasil akhir suatu kebijakan.

3. Evaluasi hasil (outcome evaluation), yang menilai hasil kebijakan dengan tujuan yang yang direncanakan pada saat kebijakan tersebut dirumuskan.

4. Meta-evaluasi, yang merupakan evaluasi terhadap berbagai hasil atau temuan evaluasi dari berbagai kebijakan yang terkait.

Berdasarkan uraian-uraian tersebut di atas, dapat dinyatakan bahwa evaluasi kebijakan merupakan proses pengukuran sejauh mana suatu kebijakan dapat mencapai tujuan yang telah ditetapkan sebelumnya yang didasarkan pada pencapaian indikatorindikator tujuan kebijakan. Pengukuran tersebut dapat dilakukan pada saat kebijakan tersebut tengah berlangsung (diimplementasikan) maupun pada saat kebijakan tersebut telah selesai dilaksanakan.

\section{RENCANA ANGGARAN SEKOLAH}

Anggaran Pendapatan dan Belanja Sekolah, yang selanjutnya disingkat APBS adalah dokumen yang memuat rencana pendapatan, belanja dan pembiayaan yang digunakan sebagai dasar pelaksanaan anggaran oleh pelaksana teknis kegiatan sekolah dalam satu tahun pelajaran yang dibahas dan disetujui bersama oleh sekolah dan komite sekolah dan disahkan oleh Kepala Dinas Pendidikan, Kepemudaan dan Olahraga.

Rencana Anggaran Pendapatan dan Belanja Sekolah, yang selanjutnya disingkat RAPBS, adalah dokumen perencanaan dan penganggaran yang berisi rencana pendapatan, rencana belanja program dan kegiatan sekolah serta rencana pembiayaan sebagai dasar penyusunan Anggaran Pendapatan dan Belanja Sekolah 


\section{SEGMEN Jurnal Manajemen dan Bisnis \\ Volume 17 No 2 Juli 2021 \\ p-ISSN: 0216-938X e-ISSN: 2684-8414}

\section{DEFINISI BANTUAN OPERASIONAL SEKOLAH}

Dana Bantuan Operasional Sekolah yang selanjutnya disebut Dana BOS adalah dana yang digunakan terutama untuk mendanai belanja nonpersonalia bagi satuan pendidikan dasar dan menengah sebagai pelaksana program wajib belajar dan dapat dimungkinkan untuk mendanai beberapa kegiatan lain sesuai dengan ketentuan peraturan perundang-undangan. Dana BOS Reguler adalah Dana BOS yang dialokasikan untuk membantu kebutuhan belanja operasional seluruh peserta didik pada satuan pendidikan dasar dan menengah.

Pengelolaan Dana BOS Reguler dilakukan berdasarkan prinsip:

1. fleksibilitas yaitu penggunaan Dana BOS Reguler dikelola sesuai dengan kebutuhan sekolah;

2. efektivitas yaitu penggunaan Dana BOS Reguler diupayakan dapat memberikan hasil, pengaruh, dan daya guna untuk mencapai tujuan pendidikan di sekolah;

3. efisiensi yaitu penggunaan Dana BOS Reguler diupayakan untuk meningkatkan kualitas belajar siswa dengan biaya seminimal mungkin dengan hasil yang optimal;

4. akuntabilitas yaitu penggunaan Dana BOS Reguler dapat dipertanggungjawabkan secara keseluruhan berdasarkan pertimbangan yang logis sesuai peraturan perundangundangan; dan

5. transparansi yaitu penggunaan Dana BOS Reguler dikelola secara terbuka dan mengakomodir aspirasi pemangku kepentingan sesuai dengan kebutuhan sekolah.

Besaran Alokasi Dana BOS Reguler diatur dengan ketentuan sebagai berikut :

1. Besaran alokasi Dana BOS Reguler dihitung berdasarkan besaran satuan biaya masing-masing daerah dikalikan dengan jumlah Peserta Didik.

2. Satuan biaya masing-masing daerah sebagaimana dimaksud pada ayat (1) ditetapkan oleh Menteri.

3. Jumlah Peserta Didik sebagaimana dimaksud pada ayat (1) dihitung berdasarkan data jumlah Peserta Didik yang memiliki NISN.

\section{GOOD GOVERNANCE}

United Nations Development Programme (UNDP) mendefinisikan good governanceseba gai hal mengenai partisipatif, transparan, dan akuntabel. Hal ini juga berkaitan dengan efektif dan adil serta menjunjung tinggi aturan hukum1. World Bank mendefinisikan good governance sebagai pembuatan kebijakan yang dapat diprediksi, terbuka dan tercerahkan; birokrasi yang dijiwai dengan etos profesional; eksekutif pemerintah yang bertanggung jawab atas tindakannya; dan masyarakat sipil yang berpartisipasi secara aktif dalam urusan publik; dan semuanya berperilaku di bawah aturan hukum2. Kaidah-kaidah yang harus dipenuhi adalah kerangka aturan (legal framework), informatif, akuntabilitas dan transparansi.

Beberapa organisasi internasional memberikan rumusan karakteristik good governance yang beragam satu sama lain sesuai pengalaman dan lingkup bidang tugasnya. United Nations Economic and Social Commission for Asia and the Pacific (UNESCAP), United Nations Development 


\section{SEGMEN Jurnal Manajemen dan Bisnis \\ Volume 17 No 2 Juli 2021 \\ p-ISSN: 0216-938X e-ISSN: 2684-8414}

Program (UNDP), dan the World Bank mengidentifikasi karakteristik good governance dengan indikator yang berbeda. Tetapi dari ketiga sumber Indikator pengukuran Good Governance yang sama adalah unsur transparansi dan akuntabilitas.

\section{TRANSPARANSI}

Sebagai salah satu pilar good governance, transparansi menurut United Nations (2007) didefinisikan sebagai keterbukaan yang dibangun atas informasi yang mengalir bebas. Informasi yang tersedia tersebut dapat dipahami dan dipantau oleh publik. Transparansi juga mempromosikan keterbukaan proses demokrasi melalui pelaporan dan masukan (feedback), kejelasan proses dan prosedur, serta perilaku dan tindakan pemegang otoritas pengambilan keputusan. Dalam konteks yang lebih luas, Oliver (2004) mendefinisikan transparansi sebagai pengungkapan aktif (active disclosure) karena masyarakat mempunyai hak untuk mendapatkan informasi publik. Oliver juga menambahkan bahwa dalam International Monetary Fund (IMF) Guidelines for Government Transparency dinyatakan transparansi fokus pada 4 (empat) aspek kunci, yaitu:

1. kejelasan peran dan tanggung jawab (clarity of roles and responsibilities)

2. ketersediaan informasi publik (public availability of information)

3. keterbukaan rencana, pelaksanaan dan pelaporan anggaran (open budget preparation, execution, and reporting)

4. jaminan integritas (assurances of integrity).

Novitaningrum (2014) menggunakan 4 indikator untuk mengukur transparansi yaitu kerangka kerja hukum, akses masyarakat, audit yang independen dan efektif, dan keterlibatan masyarakat dalam pembuatan keputusan.

\section{AKUNTABILITAS}

Kumorotomo (2008) mendefinisikan akuntabilitas (accountability) sebagai ukuran yang menunjukkan apakah pelayanan yang dilakukan oleh pemerintah sudah sesuai dengan no rma dan nilai-nilai yang dianut oleh rakyat, dan apakah pelayanan publik tersebut mampu mengakomodasi kebutuhan rakyat yang sesungguhnya. Dengan kata lain, akuntabilitas terkait dengan falsafah bahwa lembaga eksekutif pemerintah, yang tugas utamanya adalah melayani rakyat, harus bertanggung jawab secara langsung maupun tidak langsung kepada rakyat.

Kearns (1996) menambahkan bahwa sistem akuntabilitas terdiri atas 3 (tiga) elemen inti yaitu :

1. otoritas yang lebih tinggi diberikan kewenangan untuk melakukan pemantauan dan pengawasan,

2. ukuran atau kriteria untuk menilai kepatuhan atau kinerja yang dimandatkan, dan

3. mekanisme pelaporan eksplisit untuk menyampaikan informasi kepada pimpinan di level yang lebih tinggi maupun kepada lembaga pengawasan.

Mardiasmo (2002) berpendapat pola pertanggungjawaban di sektor publik bersifat vertikal dan horisontal. Pertanggungjawaban vertikal (vertical accountability) ditujukan kepada otoritas yang lebih tinggi, misalnya unit-unit kerja (dinas) kepada pemerintah daerah, atau pemerintah daerah kepada pemerintah pusat. Sementara, pertanggungjawaban horisontal (horizontal accountability) ditujukan kepada 


\section{SEGMEN Jurnal Manajemen dan Bisnis \\ Volume 17 No 2 Juli 2021 \\ p-ISSN: 0216-938X e-ISSN: 2684-8414}

masyarakat luas. Mardiasmo juga menambahkan bahwa dalam konteks organisasi pemerintah, akuntabilitas publik adalah pemberian informasi dan disclosure atas aktivitas dan kinerja pemerintah kepada pihak-pihak yang berkepentingan dalam rangka pemenuhan hak-hak publik. Tuntutan akuntabilitas publik mengharuskan lembaga sektor publik untuk lebih menekankan pada pertanggungjawaban horisontal, bukan hanya pada pertanggungjawaban vertikal.

Dari Literatur review di atas dapat diturunkan indikator pengukuran Transparansi yang digunakan dalam penelitian ini tersaji dalam Tabel 1 dan pengukuran akuntabilitas tersaji dalam Tabel 2. berikut :

Tabel 1.

\section{Indikator Transparansi}

\begin{tabular}{|c|l|l|}
\hline No & Indikator Transparansi & Literatur \\
\hline \multirow{5}{*}{1} & $\begin{array}{l}\text { Kerangka Kerja Hukum } \\
\text { 1. Adanya peraturan hukum yang menjadi } \\
\text { landasan/pedoman } \\
\text { 2. Adanya kejelasan proses dan prosedur } \\
\text { 3. Kejelasan pembagian peran dan tanggung }\end{array}$ & $\begin{array}{l}\text { IMF Guidelines dalam Oliver } \\
\text { (2004), United Nations } \\
\text { (2007), KNKG (2008), dan } \\
\text { Novitaningrum (2014) }\end{array}$ \\
\hline \multirow{2}{*}{2} & $\begin{array}{l}\text { Ketersediaan informasi publik } \\
\text { 1. Sosialisasi dan diseminasi informasi } \\
\text { 2. Kemudahan akses informasi }\end{array}$ & $\begin{array}{l}\text { IMF Guidelines dalam Oliver } \\
\text { (2004), KNKG (2008) }\end{array}$ \\
\hline 3 & $\begin{array}{l}\text { Keterbukaan rencana, pelaksanaan, dan } \\
\text { pelaporan anggaran }\end{array}$ & $\begin{array}{l}\text { IMF Guidelines dalam Oliver } \\
\text { 1. Penyusunan anggaran partisipasif }\end{array}$ \\
\hline
\end{tabular}

Sumber: dirangkum dari beberapa referensi

Tabel 2.

Indikator Akuntabilitas

\begin{tabular}{|c|l|l|}
\hline No & Indikator Akuntabilitas & Literatur \\
\hline \multirow{2}{*}{1} & $\begin{array}{l}\text { Pemantauan, pengawasan dan audit } \\
\text { 1. Pemantauan dan pengawasan oleh otoritas } \\
\text { yang lebih tinggi } \\
\text { 2. Layanan keluhan dan pengaduan }\end{array}$ & $\begin{array}{l}\text { Kearns (1996), KNKG (2008), } \\
\text { Mardiasmo (2012) }\end{array}$ \\
\hline 2 & $\begin{array}{l}\text { Pelaporan dan Pertanggungjawaban } \\
\text { 1.Adanya laporan pertanggungjawaban }\end{array}$ & $\begin{array}{l}\text { Kearns (1996), KNKG (2008), } \\
\text { KSAP (2011) }\end{array}$ \\
\hline 3 & $\begin{array}{l}\text { Pengukuran Kinerja } \\
\text { 1.Evaluasi Kinerja secara Berkala }\end{array}$ & Kearns (1996), KNKG (2008), \\
\hline
\end{tabular}

Sumber: dirangkum dari beberapa referensi

\section{METODE PENELITIAN}

Penelitian ini bersifat kualitatif dengan pendekatan analisis deskriptif yang bertujuan untuk melakukan eksplorasi dan klarifikasi pencapaian transparansi dan akuntabilitas dalam penganggaran Bantuan
Operasional Sekolah di Kabupaten Purworejo. Penelitian ini akan menggunakan sumber data primer berupa hasil wawancara dengan key informant yakni Tim Manajemen BOS Kabupaten Purworejo, serta data sekunder yang bersumber dari kepustakaan, 


\section{SEGMEN Jurnal Manajemen dan Bisnis \\ Volume 17 No 2 Juli 2021 \\ p-ISSN: 0216-938X e-ISSN: 2684-8414}

laporan dan sumber informasi lainnya. data primer berupa wawancara dilakukan untuk menggali informasi mendalam mengenai pengalokasian belanja Bantuan operasional sekolah di tiap kecamatan.Data sekunder yang digunakan adalah pustaka/literatur, laporan kegiatan, dokumen anggaran, data E-RAPBS ( Rencana Angggaran dan Pendapatan Sekolah ) dan sumber-sumber informasi lainnya yang berhubungan dengan belanja bantuan sosial. Selain itu, tinjauan pustaka/literatur juga dimaksudkan untuk merumuskan definisi dan menetapkan indikator-indikator good governance terkait transparansi dan akuntabilitas. Data utama yang dianalisis dalam penelitian ini adalah data sekunder, sedangkan data pimer digunakan sebagai unsur pendukung. Kerangka Konseptual penelitian tertuang dalam gambar 1 berikut.

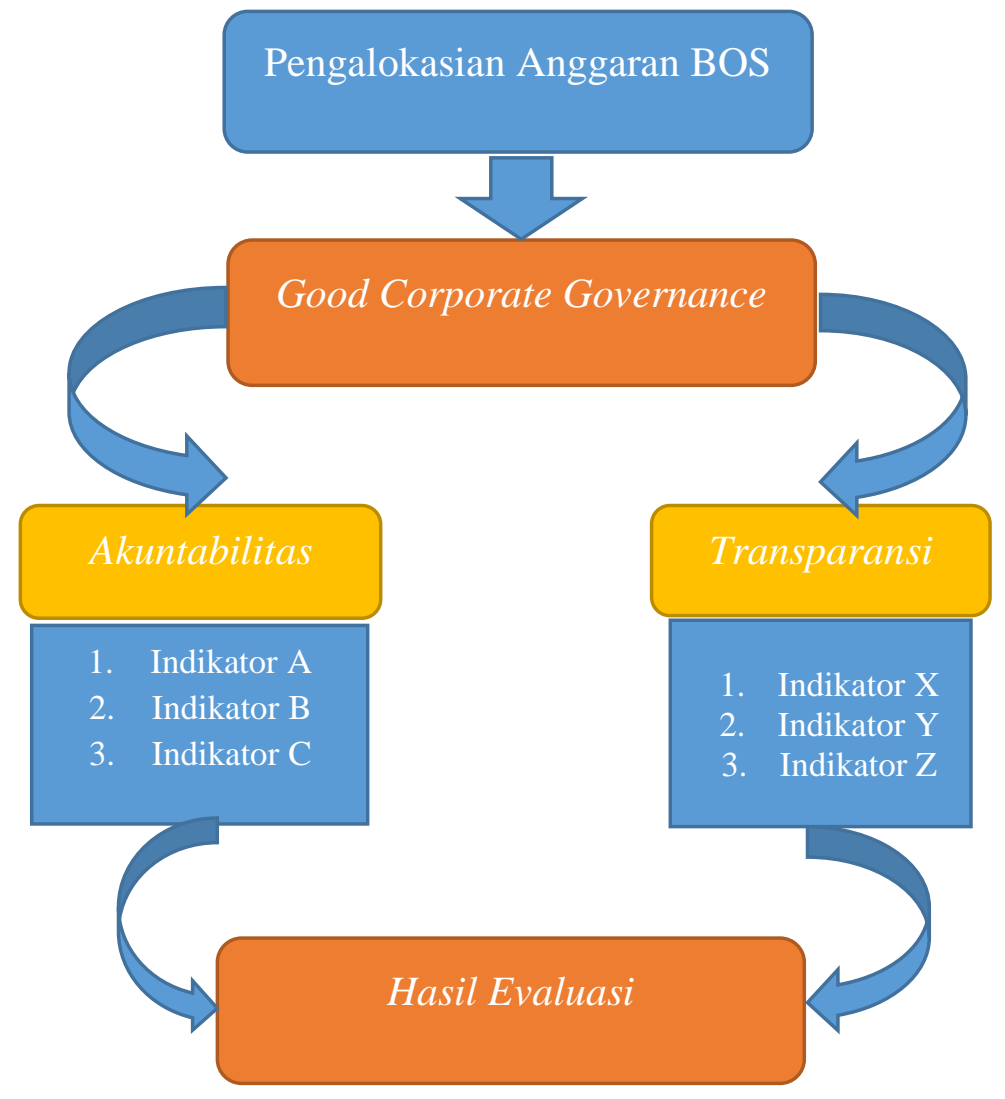

Gambar 1

Kerangka Berfikir

PEMBAHASAN

\section{Transparansi Kerangka Kerja} Hukum

Peraturan hukum yang menjadi landasan/pedoman bagi instansi pemerintah pusat dalam mengalokasikan belanja bantuan operasional sekolah (BOS ) adalah Permendikbud Nomor 6 Tahun 2021 tentang Petunjuk Teknis Pengelolaan Dana BOS Tahun 2021. Di dalamnya telah diatur secara jelas dan komprehensif tata cara pengelolaan belanja bansos mulai dari definisi, penganggaran, pelaksanaan, hingga mekanisme pertanggungjawabannya. Dari sisi penganggaran, diatur bahwa sekolah dalam mengalokasikan anggaran belanja 


\section{SEGMEN Jurnal Manajemen dan Bisnis \\ Volume 17 No 2 Juli 2021 \\ p-ISSN: 0216-938X e-ISSN: 2684-8414}

harus memperhatikan ketentuan dan kriteria sebagaimana tersebut dalam pasal 25 "Kepala sekolah menyampaikan perencanaan Dana BOS Reguler dan laporan penggunaan Dana BOS Reguler melalui sistem aplikasi pengelolaan Dana BOS pada Kementerian".

\section{- Adanya kejelasan Proses dan Prosedur}

Dalam pasal 5 Permendikbud Nomor 6

Tahun 2021 menyebutkan proses yang jelas untuk sekolah bisa melakukan proses penganggaran dan pencairan Dana BOS Reguler. Alokasi anggaran itetapkan berdasarkan Data jumlah Peserta Didik yang memiliki NISN sebagaimana dimaksud dalam Pasal 5 ayat (3) berdasarkan data pada Dapodik tanggal 31 Agustus.data sebagaimana dimaksud digunakan untuk menentukan jumlah Peserta Didik dalam penyaluran Dana BOS Reguler pada:tahap III tahun berjalan; dan tahap I dan tahap II tahun berikutnya. Sekolah kemudian bisa mendapatkan dana BOS apabila sudah di SK Kan dan dapat memantau serta mengkonfirmasi dana masuk melalui website www. bos.kemdikbud.go.id atau tampilan seperti gambar 2 berikut.

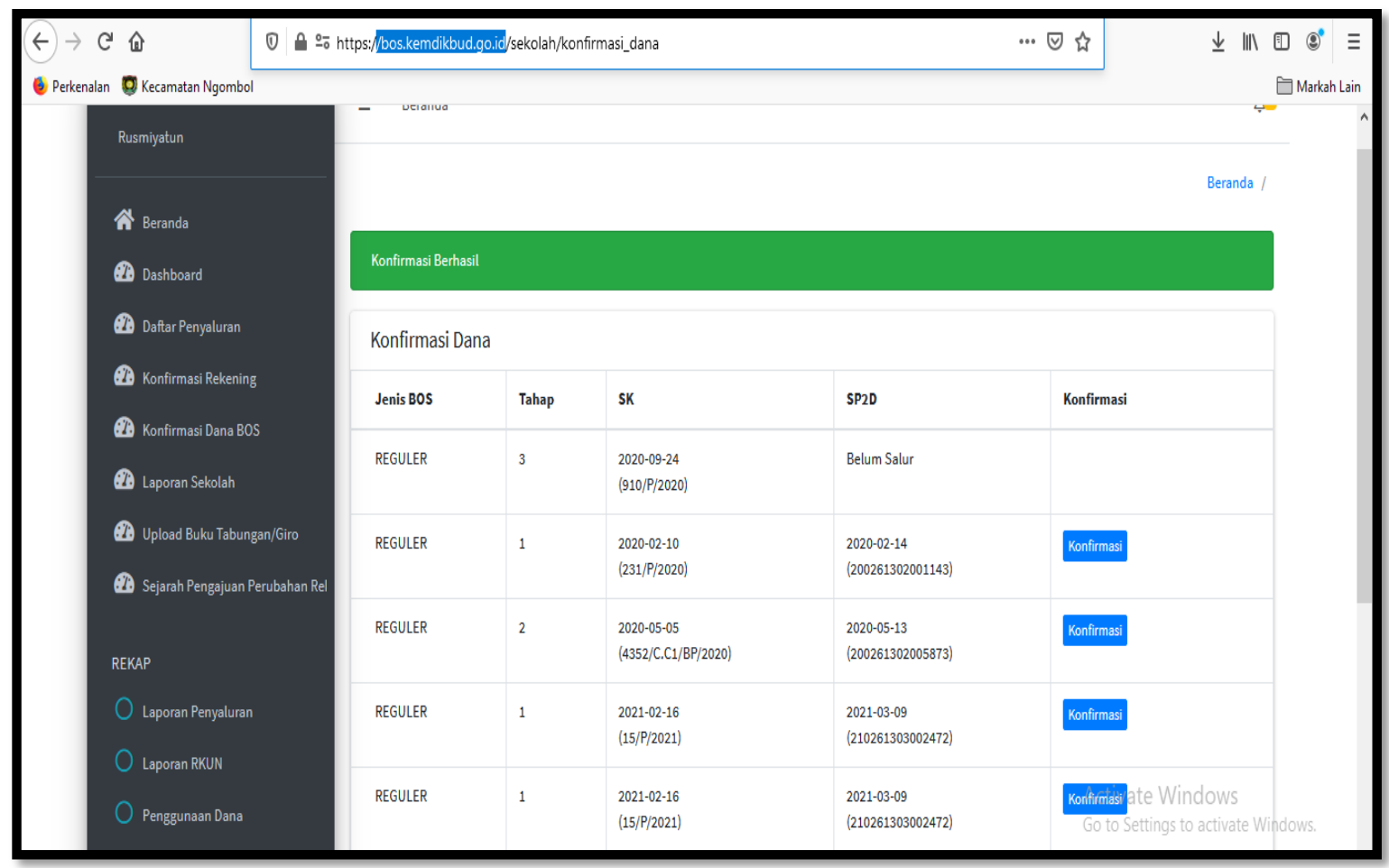

Gambar 2.

Tampilan Laman konfirmasi penyaluran dana BOS sekolah

- Kejelasan pembagian peran dan tanggung jawab

Dalam Permendikbud Nomor 6 Tahun 2021 pasal 20 disebutkan peranan dan Tanggung jawab secara hierarkis antara
Tim BOS Sekolah, kabupaten dan Kota di bidang penganggaran antara lain sebagai berikut : 


\section{SEGMEN Jurnal Manajemen dan Bisnis \\ Volume 17 No 2 Juli 2021 \\ p-ISSN: 0216-938X e-ISSN: 2684-8414}

Tabel 3.

Pembagian Peran dan Tanggung Jawab penganggaran

\begin{tabular}{|l|l|l|}
\hline \multicolumn{1}{|c|}{ Tingkat/Level } & \multicolumn{1}{|c|}{ Peran } & \multicolumn{1}{c|}{ Tanggung Jawab } \\
\hline Sekolah & $\begin{array}{l}\text { Menyusun Tim BOS Sekolah } \\
\text { Menyusun Anggaran }\end{array}$ & $\begin{array}{l}\text { Penyusunan Anggaran Secara } \\
\text { partisipasif }\end{array}$ \\
\hline Kabupaten/ Kota & Menyusun Tim BOS Kabupaten & $\begin{array}{l}\text { Sosialisasi Petunjuk Teknis } \\
\text { Monitoring Penyusunan Anggaran }\end{array}$ \\
\hline
\end{tabular}

Pemantauan dan evaluasi dilakukan oleh Tim Teknis Kabupaten/Kota,Tim Pembina Provinsi, dan Penanggung Jawab Program di Pusat untuk mengetahui sedini mungkin kendala/masalah yang dapat mengganggu pencapaian kinerja. Pemantauan dan evaluasi ini dilakukan secara berkala dan berjenjang sesuai tahapan kegiatan pengembangan usaha kelompok/lembaga. Pelaksanaan pemantauan dan evaluasi dapat dilakukan sebelum kegiatan dimulai.

\section{Ketersediaan Informasi Publik}

\section{- Sosialisasi dan Diseminasi Informasi}

Dalam permendikbud No 6 Tahun 2021 pasal 26 tentang Pembinaan, Monitoring dan Evaluasi menyebutkan bahwa Kepala Dinas melakukan pembinaan kepada kepala sekolah dalam melaksanakan tugas Pembinaan kepada kepala sekolah sebagaimana dilakukan paling sedikit melalui:sosialisasi; edukasi; pelatihan; dan bimbingan teknis.

Adapun realisasi kegiatan sosialisasi di Kabupaten Purworejo antara lain :

Tabel 4.

Realisasi Sosialisasi yang diadakan Dinas Pendidikan

\begin{tabular}{|c|c|c|c|c|}
\hline No & Jenis Sosialisasi & Sasaran & Tempat & Waktu \\
\hline 1 & $\begin{array}{l}\text { Sosialisasi } \quad \text { Penyusunan } \\
\text { Anggaran Tahun } 2020\end{array}$ & $\begin{array}{l}\text { Semua Sekolah } \\
\text { (16 Kecamatan) }\end{array}$ & $\begin{array}{l}\text { Dindikpora } \\
\text { Kab. Purworejo }\end{array}$ & $\begin{array}{l}3-16 \text { Januari } \\
2020\end{array}$ \\
\hline 2 & $\begin{array}{ll}\text { Sosialisasi Rekonsiliasi BOS } \\
\text { TW } 1\end{array}$ & $\begin{array}{l}\text { Semua Sekolah } \\
\text { (16 Kecamatan) }\end{array}$ & Zoom (online) & $3-7$ April 2020 \\
\hline 3 & $\begin{array}{l}\text { Sosialisasi Rekonsiliasi BOS } \\
\text { TW } 2\end{array}$ & $\begin{array}{l}\text { Semua Sekolah } \\
\text { (16 Kecamatan) }\end{array}$ & Zoom (online) & 4 - 9 Juli 2020 \\
\hline 4 & $\begin{array}{l}\text { Sosialisasi Rekonsiliasi BOS } \\
\text { TW } 3\end{array}$ & $\begin{array}{l}\text { Semua Sekolah } \\
\text { (16 Kecamatan) }\end{array}$ & Zoom (online) & $\begin{array}{l}2 \text { - } 9 \text { September } \\
2020\end{array}$ \\
\hline 5 & $\begin{array}{l}\text { Sosialisasi Rekonsiliasi BOS } \\
\text { TW } 4\end{array}$ & $\begin{array}{l}\text { Semua Sekolah } \\
\text { (16 Kecamatan) }\end{array}$ & Zoom (online) & $\begin{array}{l}15-17 \\
\text { Desember } 2020\end{array}$ \\
\hline 6 & $\begin{array}{l}\text { Sosialisasi Aplikasi ARKAS } \\
\text { versi } 3,0\end{array}$ & $\begin{array}{l}\text { Kecamatan Purworejo } \\
\text { (55 sekolah) }\end{array}$ & $\begin{array}{l}\text { Kecamatan } \\
\text { Purworejo }\end{array}$ & 4 Januari 2021 \\
\hline 7 & $\begin{array}{l}\text { Sosialisasi } \\
\text { Anggaran }\end{array}$ & $\begin{array}{l}\text { Semua Sekolah } \\
\text { (16 Kecamatan) }\end{array}$ & Zoom (online) & $\begin{array}{l}\text { 7-12 Januari } \\
2021\end{array}$ \\
\hline
\end{tabular}

\section{- Kemudahan akses informasi}

Akses informasi bidang penganggaran yang dilakukan oleh Kabupaten 


\section{SEGMEN Jurnal Manajemen dan Bisnis \\ Volume 17 No 2 Juli 2021 \\ p-ISSN: 0216-938X e-ISSN: 2684-8414}

Purworejo dengan melakukan beberapa hal antara lain:

1. Help desk tim manajemen BOS Kabupaten di Dindikpora Purworejo

2. Layanan keluhan dan pengaduan melalui fasilitas whatsapp, instagram, dan facebook.

Untuk website bidang penganggaran setiap sekolah diberikan user dan pasword untuk bisa mengakses di situs https://rapbs.dindikporapwr.com

3. Keterbukaan Rencana, Pelaksanaan dan Pelaporan Anggaran

- Penyusunan Anggaran Yang Partisipatif

partisipatif

Penganggaran

(participatory budgeting) merupakan pendekatan penyusunan anggaran yang melibatkan secara langsung para pemangku kepentingan, termasuk masyarakat penerima manfaat, untuk bersamasama menyusun rencana kegiatan beserta biaya yang dibutuhkan. Pendekatan ini menampung aspirasi dari daerah dan para penerima manfaat sehingga akan menumbuhkan rasa ikut memiliki (sense of belonging) yang kemudian diharapkan akan meningkatkan efektivitas dan efisiensi pelaksanaan kegiatan. Aspirasi yang berbasis bottom up planning ini kemudian akan diselaraskan dengan sasaransasaran perencanaan makro di tingkat yang nasional sehingga dapat bersinergi dengan top down policy. Anggaran ppartisipasif yang dilakukan oleh sekolah dengan melibatkan orangtua, komite dan masyarakat. Pengajuan anggaran dilakukan melalui website yang dibangun Dinas Pendidikan Kepemudaan dan Olahraga Kabupaten Purworejo.

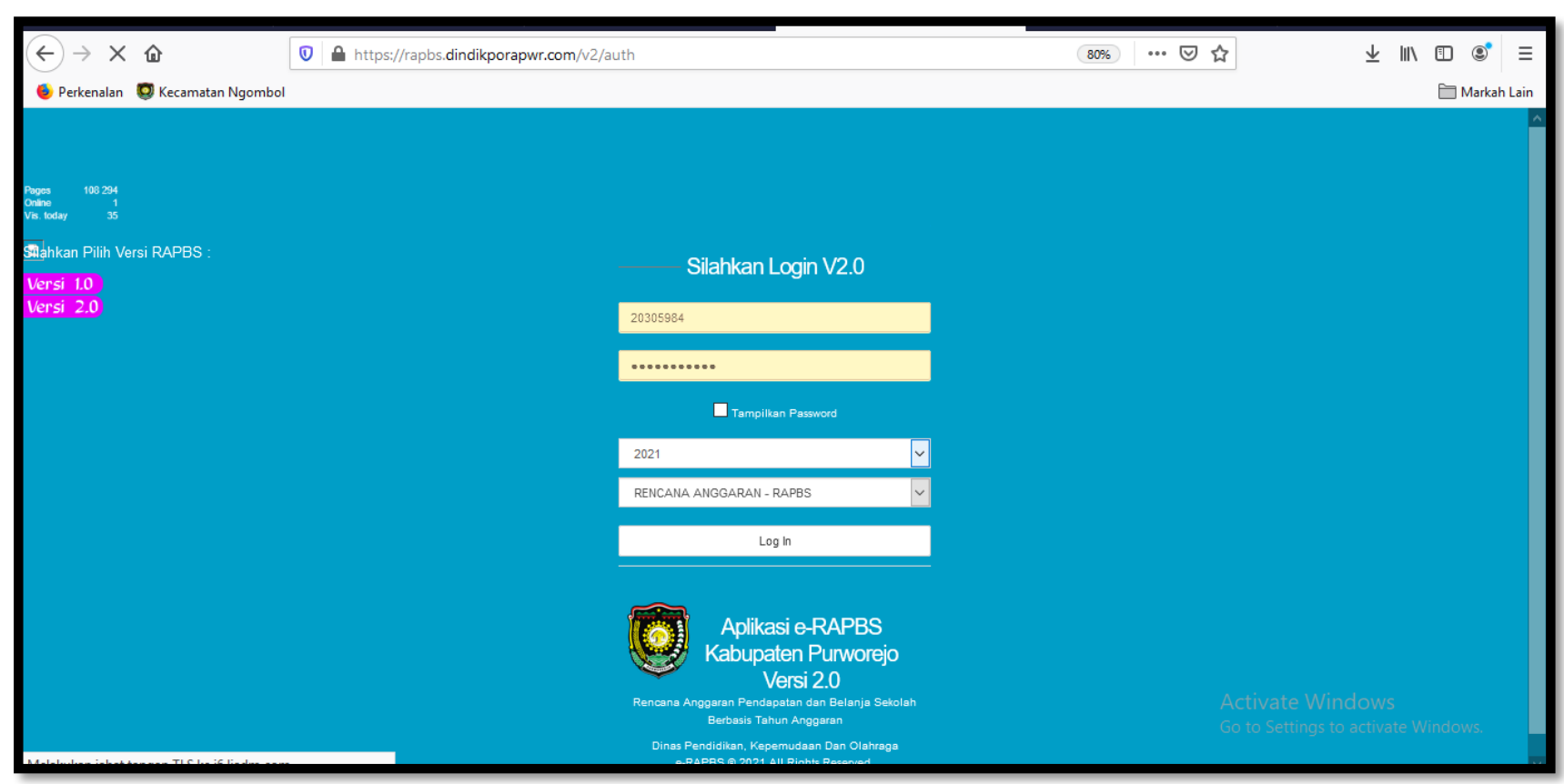

Gambar 3.

Tampilan website penganggaran di Kabupaten Purworejo 


\section{SEGMEN Jurnal Manajemen dan Bisnis \\ Volume 17 No 2 Juli 2021 \\ p-ISSN: 0216-938X e-ISSN: 2684-8414}

\section{Akuntabilitas}

\section{- Pemantauan dan Pengawasan oleh Otoritas Yang Lebih Tinggi}

Pemantuan dan pengawasan dilaksanakan dengan tujuan untuk memastikan bahwa sistem pengendalian intern dalam suatu instansi pemerintah telah dijalankan sesuai dengan yang diharapkan serta untuk memastikan bahwa perbaikanperbaikan yang dibutuhkan telah dilaksanakan. Unsur ini mencakup penilaian desain dan operasi pengendalian serta pelaksanaan tindakan perbaikan yang diperlukan. Pemantauan dan Pengawasan dilakukan oleh Dinas Pendidikan, Kepemudaan dan Olahraga Kabupaten Purworejo. Jadwal diadakan setiap 3 bulan sekali sesuai dengan penutupan tutup triwulan. Sesuai responden yang diteliti dari 477 responden mengaku semua pernah dikunjungi Dindikpora untuk kegiatan monev.

\section{- Adanya laporan pertanggungjawaban}

Adanya laporan pertanggungjawaban dari sekolah ditujukan kepada Dindikpora maupun pelaporan online terhadap kemdikbud melalui website boskemdikbud.go.id. Laporan dilaksanakan setiap triwulan. Pelaporan online juga dilakukan melalui website. Sekolah juga melaporkan anggaran maupun penggunaan anggaran melalui papan pengumuman. Dari hasil penelitian terdapat 26,7 sekolah yang belum melaporkan online penggunaan dananya di Thaun 2020. Imbasnya pencairan dana BOS pada sekolah tersebut terkendala di Tahun 2021.

\section{- Evaluasi Kinerja Secara Berkala}

Evaluasi kinerja dilaksanakan oleh instansi pemerintah setiap tahunnya untuk mengukur sejauh mana pencapaian target kinerja yang telah ditetapkan dalam dokumen penetapan kinerja. Evaluasi ini dilakukan dengan membandingkan antara target kinerja dan realisasi kinerja. Data-data yang diperlukan untuk mengukur kinerja diantaranya adalah dokumen penetapan kinerja, realisasi capaian output/outcome, pagu anggaran, dan realisasi anggaran.

Hasil pengukuran kinerja ini dituangkan dalam bentuk laporan kinerja. Peraturan yang menjadi awal dicetuskannya pengukuran kinerja ini adalah Instruksi Presiden Nomor 7 Tahun 1999 tentang Akuntabilitas Kinerja Instansi Pemerintah. Dalam inpres ini dinyatakan bahwa pelaporan kinerja instansi pemerintah dipandang perlu dalam rangka lebih meningkatkan pelaksanaan pemerintahan yang lebih berdaya guna, bersih dan bertanggung jawab. Pelaporan akuntabilitas kinerja instansi pemerintah ini juga dimaksudkan untuk mengetahui kemampuan instansi pemerintah dalam mencapai visi, misi, dan tujuan organisasi.

Peraturan selanjutnya yang menjadi landasan hukum evaluasi kinerja adalah PP Nomor 8 Tahun 2006 tentang Pelaporan Keuangan dan Kinerja Instansi Pemerintah, Dalam peraturan pemerintah ini diatur bahwa menteri/pimpinan lembaga selaku Pengguna Anggaran diminta untuk menyusun laporan kinerja setiap tahunnya. Laporan kinerja ini berisi ringkasan tentang keluaran dari masing-masing kegiatan dan hasil yang dicapai dari masing-masing program sebagaimana ditetapkan dalam dokumen pelaksanaan APBN. 


\section{SEGMEN Jurnal Manajemen dan Bisnis \\ Volume 17 No 2 Juli 2021 \\ p-ISSN: 0216-938X e-ISSN: 2684-8414}

Tabel 5.

Klasifikasi Penilaian Kinerja

\begin{tabular}{|c|c|c|c|}
\hline NO & SKOR & NILAI & INTERPRETASI DAN KARAKTERISTIK INSTANSI \\
\hline 1 & $>85$ & AA & $\begin{array}{l}\text { Memuaskan: Memimpin perubahan, berbudaya kinerja, } \\
\text { berkinerja tinggi, dan akuntabel, perlu terus berinovasi }\end{array}$ \\
\hline 2 & $>75-85$ & A & $\begin{array}{l}\text { Sangat Baik: Akuntabilitas kinerjanya baik, memiliki } \\
\text { sistem manajemen kinerja yang andal, menggunakan } \\
\text { knowledge management untuk membangun budaya } \\
\text { berkinerja, perlu banyak inovasi }\end{array}$ \\
\hline 3 & $>65-75$ & B & $\begin{array}{l}\text { Baik: akuntabilitas kinerjanya baik, memiliki sistem yang } \\
\text { dapat digunakan untuk manajemen kinerja, perlu sedikit } \\
\text { perbaikan untuk sistem dan perlu banyak berfokus pada } \\
\text { perbaikan soft systems. }\end{array}$ \\
\hline 4 & $>50-65$ & $\mathrm{CC}$ & $\begin{array}{l}\text { Cukup Baik (memadai): Akuntabilitas kinerjanya cukup } \\
\text { baik, taat kebijakan, memiliki sistem yang dapat digunakan } \\
\text { untuk memproduksi informasi kinerja bagi } \\
\text { pertanggungjawaban tapi perlu banyak perbaikan, termasuk } \\
\text { sedikit perbaikan yang mendasar }\end{array}$ \\
\hline 5 & $>30-50$ & $C$ & $\begin{array}{l}\text { Agak Kurang: Memiliki sistem untuk manajemen kinerja } \\
\text { namun kurang dapat diandalkan, perlu banyak perbaikan, } \\
\text { termasuk perbaikan yang mendasar }\end{array}$ \\
\hline 6 & $0-30$ & $\mathbf{D}$ & $\begin{array}{l}\text { Kurang: sistem dan tatanan tidak dapat diandalkan } \\
\text { untuk manajemen } \begin{array}{c}\text { kinerja, perlu banyak } \\
\text { perbaikan dan perubahan yang sangat mendasar. }\end{array}\end{array}$ \\
\hline
\end{tabular}

Dalam penilaian LAKIP, Kementerian PAN dan RB melakukan evaluasi terhadap 5 komponen yaitu: perencanaan kinerja, pengukuran kinerja, pelaporan kinerja, evaluasi kinerja, dan pencapaian kinerja. Hasil penilaian tersebut dituangkan dalam bentuk kriteria/predikat sebagai berikut:

Pencapaian kinerja anggaran belanja BOS tidak diukur secara parsial melainkan secara keseluruhan bersama dengan belanja lainnya. Belanja-belanja tersebut tergabung membentuk keluaran (output) dan kegiatan yang targetnya termuat dalam dokumen perencanaan (RPJMN dan Renstra Kabupaten/ Kota) Keluaran atau kegiatan yang ditetapkan menjadi Indikator Kinerja inilah yang akan dievaluasi pencapaiannya oleh Kementerian PAN dan RB. Capaian Tahun 2018 - 2020 Kinerja Kabupaten Purworejo ternilai AA (Sangat memuaskan).

\section{SIMPULAN}

Kajian ini dilakukan untuk mengevaluasi sejauh mana penerapan good governance dalam pengalokasian anggaran belanja Bantuan Operasional Sekolah pada Kabupaten Purworejo Kriteria yang digunakan meliputi 2 (dua) aspek yakni transparansi dan akuntabilitas yang merupakan pilar-pilar kunci good governance. Berdasarkan hasil analisis pembahasan yang telah dilakukan, pengalokasian belanja operasional Sekolah pada Kabupaten Purworejo telah memenuhi prinsip-prinsip transparansi yang diukur melalui indikator: (i) kerangka kerja hukum, (ii) ketersediaan informasi publik, dan (iii) keterbukaan rencana, pelaksanaan, dan pelaporan anggaran.

Pengalokasian belanja operasional sekolah pada Kabupaten Purworejo telah memenuhi prinsip-prinsip akuntabilitas yang diukur melalui indikator: (i) pemantauan, pengawasan dan audit, (ii) pelaporan dan pertanggungjawaban, dan (iii) pengukuran kinerja. Pemantauan dan pengawasan belanja bansos melalui jalur struktural 


\section{SEGMEN Jurnal Manajemen dan Bisnis \\ Volume 17 No 2 Juli 2021 \\ p-ISSN: 0216-938X e-ISSN: 2684-8414}

dilakukan oleh tim teknis tingkat kabupaten. Pengawasan juga dilakukan oleh otoritas yang lebih tinggi dilaksanakan oleh aparat pengawasan internal maupun eksternal pemerintah.

\section{DAFTAR PUSTAKA}

Asian Development Bank. (2004). Country Governance Assessment Report: Indonesia. Manila.

Direktorat Jenderal Anggaran Kementrian Keuangan. (2019) Evaluasi Kebijakan Alokasi Bansos di Lingkungan Kementrian Pertanian.

Fox, Jonathan. (2007). The Uncertain Relationship Between Transparency and Accountability. Development in Practice. Vol. 17 Numbers 4-5. p.663671. August 2007.

Hariswati, Nurul.(2019) . Analisa Akuntabilitas dan Transparansi tentang Kebijakan Pengelolaan BOS. Jurnal Ekonomika dan Bisnis Vol 6 hal 75.87

International Monetary Fund. (2019). Government Finance Statistics Manual 2019. Washington, D.C.

Kearns, Kevin P. (1996). Managing for Accountabiliy : Preserving the Public Trust in Public and Nonprofit Organizations. San Fransisco: JosseyBass Publishers.

Komite Nasional Kebijakan Governance. (2008). Pedoman Umum Good Public Governance Indonesia, Jakarta.

Lester, James P., \& Stewart, Joseph Jr. (2000). Public Policy: An Evolutionary Approach. Belmont: Wadsworth.

Mardiasmo. (2002). Akuntansi Sektor Publik. Yogyakarta: Penerbit ANDI.
Novitaningrum, Badzlina D. (2014).

Akuntabilitas dan Transparansi

Pengadaan Barang dan Jasa

Pemerintah melalui Electronic

Procurement (Best Practice di

Pemerintah Kota Surabaya). Jurnal

Kebijakan dan Manajemen Publik.

Vol. 2 No.1, Januari 2014.

Oliver, Richard W. (2004). What is

Transparency. New York: McGrawHill.

Peraturan Menteri Pendidikan dan Kebudayaan RI Nomor 6 Tahun 2021 tentang Petunjuk Teknis BOS Reguler Tahun 2021.

Surat Edaran Dindikpora No.421.92/2021. (2021) Petunjuk Teknis Penyusunan Anggaran BOS Tahun 2021 di Kabupaten Purworejo.

UNESCAP. (2006). What is Good

Governance. Bangkok: United

Nations Economic and Social

Commission for Asia and the Pacific.

World Bank. (2003). Social Risk Management: The World Bank's Approach to Social Protection in a Globalizing World. Washington, D.C. https://rapbs.dindikporapwr.com. Diakses pada tanggal 30 Maret 2021

https://bos.kemdikbud.go.id. Diakses pada tanggal 26 Maret 2021 